University of Nebraska - Lincoln

DigitalCommons@University of Nebraska - Lincoln

Agronomy \& Horticulture - Faculty Publications

Agronomy and Horticulture Department

2012

\title{
Registration of 'NE01481' Hard Red Winter Wheat
}

\author{
P. Stephen Baenziger \\ University of Nebraska-Lincoln, pbaenziger1@unl.edu \\ Robert A. Graybosch \\ USDA-ARS, bob.graybosch@ars.usda.gov \\ Teshome H. Regassa \\ University of Nebraska-Lincoln, tregassa2@unl.edu \\ Lenis Alton Nelson \\ University of Nebraska-Lincoln, Inelson1@unl.edu \\ Robert N. Klein \\ West Central Res. and Ext. Center, robert.klein@unl.edu
}

See next page for additional authors

Follow this and additional works at: https://digitalcommons.unl.edu/agronomyfacpub

Part of the Plant Sciences Commons

Baenziger, P. Stephen; Graybosch, Robert A.; Regassa, Teshome H.; Nelson, Lenis Alton; Klein, Robert N.; Santra, Dipak K.; Baltensperger, D. D.; Xu, Lei; Wegulo, Stephen N.; Jin, Y.; Kolmer, J.; Chen, Ming-Shun; and Bai, Guihua, "Registration of 'NE01481' Hard Red Winter Wheat" (2012). Agronomy \& Horticulture -- Faculty Publications. 605.

https://digitalcommons.unl.edu/agronomyfacpub/605

This Article is brought to you for free and open access by the Agronomy and Horticulture Department at DigitalCommons@University of Nebraska - Lincoln. It has been accepted for inclusion in Agronomy \& Horticulture -Faculty Publications by an authorized administrator of DigitalCommons@University of Nebraska - Lincoln. 


\section{Authors}

P. Stephen Baenziger, Robert A. Graybosch, Teshome H. Regassa, Lenis Alton Nelson, Robert N. Klein, Dipak K. Santra, D. D. Baltensperger, Lei Xu, Stephen N. Wegulo, Y. Jin, J. Kolmer, Ming-Shun Chen, and Guihua Bai 


\title{
Registration of 'NE01481' Hard Red Winter Wheat
}

\author{
P. S. Baenziger, ${ }^{\star}$ R. A. Graybosch, T. Regassa, L. A. Nelson, R. N. Klein, D. K. Santra, \\ D. D. Baltensperger, L. Xu, S. N. Wegulo, Y. Jin, J. Kolmer, Ming-Shun Chen, and Guihua Bai
}

\begin{abstract}
'NE01481' (Reg. No. CV-1061, PI 659689) hard red winter wheat (Triticum aestivum L.) was developed cooperatively by the Nebraska Agricultural Experiment Station and the USDA-ARS and released in April 2010. NE01481 will be marketed as Husker Genetics brand McGill. In addition to superior agronomic performance, Nebraska wheat growers would like to have increased resistance to Wheat soilborne mosaic virus. NE01481 was selected from the cross NE92458/'Ike' that was made in 1995. The pedigree of NE92458 is OK83201/'Redland' and the pedigree of OK83201, an experimental line developed by Oklahoma State University is 'Vona'//'Chisholm'/'Plainsman V'. NE01481 was selected with the bulkbreeding method as an $\mathrm{F}_{3: 4}$ line in 1999, and in 2001 it was assigned experimental line number NE01481. NE01481 was released because of its superior grain yield in rainfed wheat production systems in southeastern, south central, and southwestern Nebraska and that it is the first modern release from our program with resistance to Wheat soilborne mosaic virus.
\end{abstract}

$\mathbf{W}$ heat soilborne mosaic virus (SBWMV) in an increasing problem in southeastern and south central Nebraska, from where it continues to spread north and west. The most common methods of controlling the virus are the

P.S. Baenziger, T. Regassa, L.A. Nelson, and L. Xu, Dep. of Agronomy and Horticulture; R.A. Graybosch, USDA-ARS and Dep. of Agronomy and Horticulture; S.N. Wegulo, Dep. of Plant Pathology, Univ. of Nebraska, Lincoln, NE 68583; R.N. Klein, Dep. of Agronomy and Horticulture, West Central Res. and Ext. Center, North Platte, NE 69101; D.K. Santra, Dep. of Agronomy and Horticulture, Panhandle Research and Extension Center, Scottsbluff, NE 69361; D.D. Baltensperger, (formerly Dep. of Agronomy and Horticulture, Univ. of Nebraska, Lincoln, NE 68583) Soil and Crop Sciences Dep., Texas A\&M Univ., College Station, TX 77843; Y. Jin and J. Kolmer, USDAARS and Dep. of Plant Pathology, Univ. of Minnesota, St. Paul, MN 55108; Ming-Shun Chen, USDA-ARS, Center for Grain and Animal Health Research and Dep. of Entomology, Kansas State University; Guihua Bai, USDA-ARS, Center for Grain and Animal Health Research and Dep. of Agronomy, Kansas State Univ., Manhattan, KS 66506. Registration by CSSA. Received 23 Feb. 2011. *Corresponding author (pbaenziger1@unl.edu).

\begin{abstract}
Abbreviations: FHB, Fusarium head blight; NESVT, Nebraska State Variety Trial; SRPN, Southern Regional Performance Nursery; SBWMV, Wheat soilborne mosaic virus.
\end{abstract}

Published in the Journal of Plant Registrations 6:49-53 (2012) doi: 10.3198/jpr2011.02.0101crc

Posted online 8 Sept. 2011

(C) Crop Science Society of America

5585 Guilford Rd., Madison, WI 53711 USA

All rights reserved. No part of this periodical may be reproduced or transmitted in any form or by any means, electronic or mechanical, including photocopying, recording, or any information storage and retrieval system, without permission in writing from the publisher. Permission for printing and for reprinting the material contained herein has been obtained by the publisher. use of resistant cultivars and late-planted susceptible cultivars, which have reduced infection because of the low temperature at planting (Myers et al., 1993). However, with recent warm fall weather, even late-planted wheat has suffered considerable losses in grain yield due to the disease. 'NE01481' (Reg. No. CV-1061, PI 659689) hard red winter wheat (Triticum aestivum L.) was tested under the experimental line designation NE01481 and was developed cooperatively by the Nebraska Agricultural Experiment Station and the USDA-ARS and released in 2010. NE01481 will be marketed and sold as Husker Genetics brand McGill. The brand name McGill is in honor of the late Dr. David P. McGill, who was a legendary undergraduate teacher and professor of genetics at the University of Nebraska. NE01481 was released because of its superior grain yield in rainfed wheat production systems in southeastern, south central, and southwestern NE and its resistance to SBWMV, a major potential disease in this region.

\section{Methods}

NE01481 was selected from the cross NE92458/Ike that was made in spring 1995. The pedigree of NE92458 is OK83201/'Redland' (Schmidt et al., 1989), and the pedigree of OK83201, an experimental line developed by Oklahoma State University, is 'Vona' (Welsh et al., 1978)//'Chisholm' (Smith et al., 1985)/'Plainsman V' (PI 591702). The $\mathrm{F}_{1}$ generation was grown in the greenhouse in 1996, and the $F_{2}$ and $\mathrm{F}_{3}$ generations were advanced via a modified bulkbreeding method in the field at Ithaca, NE in 1997-1998. The seeding rate was $66 \mathrm{~kg} \mathrm{ha}^{-1}$. The $\mathrm{F}_{2}$ bulk was a single four-row plot that was $2.4 \mathrm{~m}$ long with $30 \mathrm{~cm}$ between rows. After a mild culling selection of less than $15 \%$ to remove very poor bulks (usually based on poor winter 
survival, but also on poor disease resistance, extreme lateness, or lodging), the $\mathrm{F}_{3}$ bulks were planted in September 1997 in an unreplicated bulk nursery, each as a four-row plot that was $5 \mathrm{~m}$ long with $30 \mathrm{~cm}$ between rows. Approximately $50 \%$ of the $\mathrm{F}_{3}$ populations were visually selected on the basis of winter survival, disease resistance, and general agronomic appearance (mainly plant height, flowering date, standability, and visually estimated yield potential). Each selected population was advanced by randomly sampling approximately 100 spikes, although especially promising bulks had a sample of 200-300 spikes selected in July 1998. Selected spikes were threshed individually and planted in a headrow nursery in September 1998. Headrow selections were planted as a single row that was $0.9 \mathrm{~m}$ long with $30 \mathrm{~cm}$ between rows. Headrows were selected visually on the basis of uniformity and agronomic appearance. In 1999-2000, the line was evaluated as a single plot in an observation nursery. Harvested samples were evaluated for end-use quality with the Mixograph (National Manufacturing Co., Lincoln, NE) and on the basis of protein content (Baenziger et al., 2001b). In 2000-2001, the line eventually designated at NE01481 was grown at six locations in Nebraska. There was no further selection.

From fall 2001 onward, NE01481 was evaluated in replicated trials in Nebraska and the Great Plains: (i) an advanced trial in 2001-2002; (ii) an elite trial in 20022010; (iii) the USDA-ARS-coordinated Southern Regional Performance Nursery (SRPN) in 2004-2005; and (iv) the Nebraska State Variety Trial (NESVT) from 2005 to 2010. The NESVT is planted annually at 13-15 rainfed and 2 or 3 irrigated locations in Nebraska or combined with locations in Wyoming that are near the Nebraska border. Normally 1-3 locations are lost yearly due to hail, freezes, drought, or severe disease.

The criteria for selection were good winter survival (determined at Ithaca, NE), resistance to stem rust (caused by Puccinia graminis Pers.:Pers. f. sp. tritici Eriks \& E. Henn.) and other diseases prevalent in the field, uniformity, and general agronomic appearance. The traits for the latter included plant height (measured from the soil surface to the tip of the spikes, excluding the awns), flowering date (measured as the number of days after 1 January to when $50 \%$ of the emerged spikes had extruded anthers), standability (measured on a scale of 1 to 10, with 1 denoting little to $10 \%$ lodging, and 10, 100\% lodging), grain yield, and grain volume weight. Over the winter, all of the lines were evaluated in the greenhouse in Lincoln, NE for their resistance to stem rust with race TPMK (with methods described in Sidiqi et al., 2009) and at the USDA-ARS Cereal Disease Laboratory with races TPMK, QCRS, RCRS, TTTT, and $\mathrm{RKQQ}$ in the greenhouse and a composite of races (RCRS, QR+FCS, QTHJ, RKQQ, and TPMK) in the field for the advanced nursery (with methods described in Rouse et al., 2011). In addition, the lines were evaluated at the Cereal Disease Laboratory for leaf rust (caused by P. triticina Eriks) in the greenhouse (methods described in Watkins et al., 2001 and Kolmer et al., 2009) and in the field (data from the regional performance nurseries using naturally occurring isolates) for leaf rust and stripe rust (caused by $P$. striiformis Westendorp f. sp. tritici). For SBWMV, the lines were screened in the field at Lincoln and in the regional performance nurseries with naturally occurring strains (with methods described in Hunger et al., 1989).

The lines were evaluated in the greenhouse for Fusarium head blight (FHB; caused by Fusarium graminearum Schwabe). Each spike was artificially inoculated with a spore suspension of an isolate of $F$. graminearum at $1 \times$ $10^{5}$ spores $\mathrm{mL}^{-1}$ at mid-anthesis by means of a handheld bottle sprayer. To obtain the spore suspension, an isolate of $F$. graminearum obtained from a Nebraska wheat field was grown on potato dextrose agar plates on a laboratory bench for $3 \mathrm{wk}$. Sterile distilled water $(5 \mathrm{~mL})$ was added to each plate and a rubber policeman was used to dislodge spores. The spore suspension was filtered through two layers of cheesecloth into a beaker and the concentration was adjusted to $1 \times 10^{5}$ spores $\mathrm{mL}^{-1}$ with distilled water. Approximately $2 \mathrm{~mL}$ of the spore suspension was applied to each spike with a handheld bottle sprayer, and the spike was then covered with a transparent plastic bag for $7 \mathrm{~d}$ following inoculation. The severity (\%) of FHB was visually estimated $14 \mathrm{~d}$ after inoculation. In the field, nurseries for natural infection, inoculation without irrigation, and inoculation with irrigation were used to evaluate the lines (with methods described in Wegulo et al., 2011). The lines were also evaluated for their resistance to Hessian fly [Mayetiola destructor (Say)] by the USDA-ARS Center for Grain and Animal Health Research (methods described in Chen et al., 2009). For end-use quality, the advanced lines were evaluated with grain samples from western Nebraska (e.g., those harvested locations other than Lincoln or Ithaca that were harvested for seed). The samples were composited and analyzed for milling and bread-baking properties using $100-\mathrm{g}$ pup loaves, where the bake sample mix time, water absorption, baked-loaf volume, and external and internal grain and texture were measured by approved methods as previously described (AACC, 2000; Baenziger et al., 2001b; Baenziger et al., 2008).

\section{Statistical Analyses}

Data for NE01481 were derived from the elite and advanced breeding trials and analyzed with an incomplete block design (incomplete block size $=5$ ) within blocks (block size $=$ 60) with Agrobase GEN II (Agronomix Software, Winnipeg, Canada; Stroup et al., 1994). Occasionally, advanced and elite trials with three or more replications were analyzed with the nearest neighbor procedure of Agrobase GEN II (Stroup et al., 1994). Because Nebraska has three major wheat-producing regions (Peterson, 1992), the data were analyzed within a location within a region and rarely across locations for the advanced and elite trials. Location means and ranks were studied, and lines were selected for having excellent performance within a location, across locations within a region, and all locations within a year based on the arithmetic mean of the adjusted means or across locations and years based on the arithmetic mean of the adjusted means. A truncated selection procedure was used as a risk-avoidance strategy (basically if a line did well in 1 or $2 \mathrm{yr}$ for grain yield, winter survival, disease 
resistance, or end-use quality and then poorly in the next year's evaluations, the line was not continued because it might perform poorly in a producer's field). Analyses of the SRPN data used SAS (SAS Institute Inc., Cary, NC) for a randomized complete block design within locations and across locations within a year. The SRPN entries were analyzed and compared for statistical significance within years due to many entries being tested for only $1 \mathrm{yr}$. For the NESVT, the trials were analyzed with SAS and a row-and-column correction (PROC MIXED) for each location and analyzed across years within a region. Entries varied greatly across regions, hence analysis across regions and locations was not done with SAS, but the arithmetic means of lines in common were considered. Only entries common to the trials across years within a region in the NESVT (2005-2009) were analyzed with randomized complete block designs.

\section{Characteristics}

\section{Agronomic and Botanical Description}

NE01481 is an awned cultivar with tan glumes that expresses a semidwarf stature (it contains the RhtB1b allele [formerly Rht1]). The coleoptile of NE01481 is white and the juvenile growth habit is prostrate. The foliage is green with a light waxy bloom on the leaf sheath and spike at anthesis but not on the leaves. The flag leaf is recurved and not twisted at the boot stage. After heading, the canopy is moderately closed and inclined to nodding. The leaves are glabrous. The spike is tapering, narrow, midlong, and middense. The glume is long and midwide, and the glume shoulder is square. The beak is moderately long with an acuminate tip. The spike is predominantly nodding at maturity with some spikes inclined. Kernels are red, hard textured, and mainly ovate in shape. The kernel has a small to nonexistent collar, a large, long brush, rounded cheeks, large germ, and a narrow and shallow crease.

The coleoptile length of NE01481 $(78 \mathrm{~mm} \pm 1 \mathrm{~mm})$ is similar to that of Husker Genetics brand Overland ('NE01643', $79 \pm 1 \mathrm{~mm}$; Baenziger et al., 2008), 'Infinity CL' (83 $\pm 2 \mathrm{~mm}$; Baenziger et al., 2006), and 'Wesley' (75 $\pm 1 \mathrm{~mm}$; Peterson et al., 2001), but it is shorter than that of conventional height cultivars such as 'Goodstreak' (109 $\pm 1 \mathrm{~mm}$; Baenziger et al., 2004) and 'Scout 66' (114 $\pm 1 \mathrm{~mm}$; Schmidt et al., 1971).

Although considerable data were available from the breeding nurseries during line development, the majority of data presented here is from the SRPN (http://www.ars .usda.gov/Research/docs.htm?docid=11932; verified 28 July 2011) and the NESVT (Table 1; complete report available at http://varietytest.unl.edu/winterwheat.html; verified 28 July 2011). In the SRPN, NE01481 ranked 27 out of 50 in 2004 and 19 out of 48 in 2005 for grain yield (3893 $\mathrm{kg} \mathrm{ha}^{-1}$ in 2004; $3624 \mathrm{~kg} \mathrm{ha}^{-1}$ in 2005). NE01481 compared favorably with 'Trego', the highest-yielding check cultivar (3939 $\mathrm{kg} \mathrm{ha}^{-1}$ in 2004 and $3284 \mathrm{~kg} \mathrm{ha}^{-1}$ in 2005). In other measures of performance, NE01481 had lower grain volume weight (74.5 $\mathrm{kg} \mathrm{hL}^{-1}$ ) than Trego (77.0 $\left.\mathrm{kg} \mathrm{hL}^{-1}\right)$ and 'TAM 107'

Table 1. Agronomic traits by district in Nebraska for rainfed environments grown from 2005 to $2009 .^{\dagger}$

\begin{tabular}{|c|c|c|c|c|c|c|c|c|c|c|}
\hline Cultivar & Yield & $\begin{array}{c}\text { Grain } \\
\text { volume } \\
\text { weight }\end{array}$ & $\begin{array}{c}\text { Grain } \\
\text { protein } \\
\text { content }\end{array}$ & Lodging & $\begin{array}{c}\text { Plant } \\
\text { height }\end{array}$ & Yield & $\begin{array}{c}\text { Grain } \\
\text { volume } \\
\text { weight }\end{array}$ & $\begin{array}{c}\text { Grain } \\
\text { protein } \\
\text { content }\end{array}$ & Lodging & $\begin{array}{c}\text { Plant } \\
\text { height }\end{array}$ \\
\hline & $\mathrm{kg} \mathrm{ha}^{-1}$ & $\mathrm{~kg} \mathrm{hL}^{-1}$ & $\mathrm{~g} \mathrm{~kg}^{-1}$ & $\%$ & $\mathrm{~cm}$ & $\mathrm{~kg} \mathrm{ha}^{-1}$ & $\mathrm{~kg} \mathrm{hL}^{-1}$ & $\mathrm{~g} \mathrm{~kg}^{-1}$ & $\%$ & $\mathrm{~cm}$ \\
\hline & \multicolumn{5}{|c|}{ Southeast } & \multicolumn{5}{|c|}{ South Central } \\
\hline Camelot & 4307 & 74.9 & 121 & 5 & 90 & 3480 & 68.7 & 132 & 15 & 95 \\
\hline Infinity CL & 4461 & 75.9 & 118 & 9 & 89 & 3454 & 70.9 & 125 & 15 & 93 \\
\hline Millennium & 4300 & 75.2 & 120 & 2 & 91 & 3830 & 71.3 & 128 & 7 & 96 \\
\hline NE01481 (McGill) & 4596 & 74.8 & 115 & 4 & 90 & 3494 & 69.0 & 124 & 16 & 95 \\
\hline Overland & 4730 & 76.1 & 120 & 1 & 86 & 4031 & 70.5 & 128 & 7 & 95 \\
\hline Scout 66 & 3151 & 72.3 & 124 & 26 & 99 & 2553 & 51.9 & 130 & 32 & 100 \\
\hline Wesley & 3984 & 71.7 & 120 & 1 & 82 & 3830 & 67.4 & 126 & 7 & 88 \\
\hline Average all entries ${ }^{\ddagger}$ & 4074 & 73.7 & 120 & 6 & 87 & 3449 & 66.7 & 128 & 13 & 93 \\
\hline \multirow[t]{2}{*}{$\operatorname{LSD}(0.05)^{\S}$} & 376 & 3.0 & 3 & 14 & 4 & 393 & NS & 4 & 17 & 4 \\
\hline & \multicolumn{5}{|c|}{ West Central } & \multicolumn{5}{|c|}{ West } \\
\hline Camelot & 4199 & 75.2 & 121 & 8 & 89 & 3299 & 76.3 & 109 & & 74 \\
\hline Infinity CL & 4112 & 76.2 & 117 & 8 & 87 & 3326 & 76.6 & 110 & & 74 \\
\hline Millennium & 4179 & 76.8 & 120 & 4 & 91 & 3185 & 76.6 & 110 & & 76 \\
\hline NE01481 (McGill) & 4226 & 73.4 & 114 & 8 & 89 & 3171 & 76.3 & 107 & & 74 \\
\hline Overland & 4307 & 76.3 & 117 & 5 & 89 & 3346 & 76.8 & 107 & & 75 \\
\hline Scout 66 & 3286 & 77.2 & 121 & 41 & 101 & 2889 & 76.7 & 109 & & 85 \\
\hline Wesley & 4065 & 74.0 & 119 & 6 & 79 & 3064 & 74.9 & 114 & & 66 \\
\hline Average all entries ${ }^{\ddagger}$ & 3966 & 75.4 & 118 & 10 & 88 & 3159 & 76.5 & 108 & & 74 \\
\hline $\operatorname{LSD}(0.05)^{\S}$ & 310 & 0.9 & 4 & 8 & 3 & 188 & 1.2 & 4 & & 4 \\
\hline
\end{tabular}

\footnotetext{
TSoutheast, $n=13$; south central, $n=5$; west central, $n=20$; west, $n=23$.
}

${ }^{\ddagger}$ Average of all the values for the traits for the entries that were in the trial and includes values for many experimental lines not shown in the table.

$\S$ Calculated from the analysis of variance using all of the values of the entries that were in the trial including many experimental lines not shown in the table. 
peak was $3.4 \mathrm{~min}$, and mix-time tolerance was scored as 3.6) and were lower than those of Wesley (Mixograph mixtime peak of $4.7 \mathrm{~min}$ and mix time tolerance scored as 4.5). The average baking absorption $\left(602 \mathrm{H}_{2} \mathrm{O} \mathrm{g} \mathrm{kg}{ }^{-1}\right)$ was lower than that of Wesley $\left(611 \mathrm{H}_{2} \mathrm{O} \mathrm{g} \mathrm{kg}{ }^{-1}\right)$ for the corresponding years. The average loaf volume of NE01481 $\left(864 \mathrm{~cm}^{3}\right)$ was lower than that of Wesley $\left(947 \mathrm{~cm}^{3}\right)$. The scores for the external loaf score, internal crumb grain, and texture ranged from 3.6 to 3.8 (where 6 is excellent and 4 is good), which was less than those for Wesley, which ranged from 4.3 to 4.5 . The overall end-use quality characteristics for NE01481 (scored as 3.7, where 6 is excellent and 4 is good) was lower than for Wesley (4.3) but similar to many commonly grown wheat cultivars. NE01481 should be acceptable to the milling and baking industries.

\section{Seed Purification and Increase}

Seed purification of NE01481 began in 2003 and continued thereafter by means of visual identification and manual removal of variants (primarily tall, awnless, or red-chaffed off-types) from bulk-seed increases grown under rainfed conditions at Lincoln and Ithaca, NE. NE01481 has been uniform and stable since 2007 . Less than $0.5 \%$ of the plants were rogued from the breeder's seed increase in 2007-2009. The rogued variant plants were taller $(5-15 \mathrm{~cm})$ or awnless or had red chaff. Up to 1\% (10:1000) variant plants may be encountered in subsequent generations.

\section{Availability}

The Nebraska Foundation Seed Division, University of Nebraska-Lincoln, Lincoln, NE 68583 had foundation seed available under the marketing name Husker Genetics brand McGill to qualified certified seed enterprises beginning in 2010. The seed classes will be Breeder, Foundation, Registered, and Certified. Registered seed will be a nonsalable class. NE01481 has been submitted for U.S. Plant Variety Protection under P. L. 10577 with the certification option. A research and development fee will be assessed on all certified seed sales. Small quantities of seed for research purposes may be obtained from Dr. P. S. Baenziger and the Department of Agronomy and Horticulture, University of Nebraska-Lincoln for at least $5 \mathrm{yr}$ from the date of this release. A seed sample has been deposited in the USDA-ARS National Center for Genetic Resources Preservation and in the USDA-ARS National Small Grains Collection, Aberdeen ID, and seed is freely available to interested researchers.

\section{Acknowledgments}

The Nebraska Crop Improvement Association provided technical assistance in describing the cultivar characteristics and accomplishing technology transfer. NE01481 was developed with partial financial support from the Nebraska Agricultural Experiment Station, the Nebraska Wheat Development, Utilization, and Marketing Board, and BASF Corporation. Partial funding for P.S. Baenziger is from Hatch project NEB22-328, USDA-IFAFS competitive grant 2001-04462; USDA, NRICGP 00-353000-9266 and 2004-35300-1470; USDA, CSREES NRICAP grant number 2006-55606-16629; USDA OREI 2007-51300-03785; and USDA under Agreement No. 59-0790-4-092, which is a cooperative project with the U.S. Wheat and Barley Scab Initiative. Any opinions, findings, conclusions, or recommendations expressed in this publication are those of the authors and do not necessarily reflect the view of the USDA. This research comprises cooperative investigations of the Nebraska Agric. Res. Div., the Univ. of Nebraska, and the USDA-ARS.

\section{References}

American Association of Cereal Chemists (AACC). 2000. Approved methods. 10th ed. Am. Assoc. Cereal Chem., St. Paul, MN.

Baenziger, P.S., B. Beecher, R.A. Graybosch, D.D. Baltensperger, L.A. Nelson, J.M. Krall, et al. 2006. Registration of 'Infinity CL' wheat. Crop Sci. 46:975-977. doi:10.2135/cropsci2005.05-0044

Baenziger, P.S., B. Beecher, R.A. Graybosch, D.D. Baltensperger, L.A. Nelson, J.M. Krall, et al. 2004. Registration of 'Goodstreak' wheat. Crop Sci. 44:1473-1474. doi:10.2135/cropsci2004.1473

Baenziger, P.S., B. Beecher, R.A. Graybosch, A.M.H. Ibrahim, D.D. Baltensperger, L.A. Nelson, et al. 2008. Registration of 'NE01643' wheat. J. Plant Reg. 2:36-42. doi:10.3198/jpr2007.06.0327crc

Baenziger, P.S., R.A. Graybosch, L.A. Nelson, R.N. Klein, D.D. Baltensperger, L. Xu, et al. 2009. Registration of 'Camelot' wheat. J. Plant Reg. 3:256-263. doi:10.3198/jpr2009.05.0256crc

Baenziger, P.S., B. Moreno-Sevilla, C.J. Peterson, D.R. Shelton, R.W. Elmore, P.T. Nordquist, et al. 2001a. Registration of 'Millennium' wheat. Crop Sci. 41:1367-1369. doi:10.2135/cropsci2001.4141367x

Baenziger, P.S., D.R. Shelton, M.J. Shipman, and R.A. Graybosch. 2001b. Breeding for end-use quality: Reflections on the Nebraska experience. Euphytica 119:95-100. doi:10.1023/A:1017583514424

Chen, M.S., E. Echegaray, R.J. Whitworth, H.Y. Wang, P.E. Sloderbeck, A. Knutson, et al. 2009. Virulence analysis of Hessian fly populations from Texas, Oklahoma, and Kansas. J. Econ. Entomol. 102:774-780. doi:10.1603/029.102.0239

Hunger, R.M., C.R. Armitage, and J.L. Sherwood. 1989. Effects of wheat soilborne mosaic virus on hard red winter wheat. Plant Dis. 73:949-952. doi:10.1094/PD-73-0949

Kolmer, J.A., D.L. Long, and M.E. Hughes. 2009. Physiological specialization of Puccinia triticina on wheat in the United States in 2007. Plant Dis. 93:538-544. doi:10.1094/PDIS-93-5-0538

Myers, L.D., J.L. Sherwood, W.C. Siegerist, and R.M. Hunger. 1993. Temperature-influenced virus movement in expression of resistance to soilborne wheat mosaic virus in hard red winter wheat (Triticum aestivum). Phytopathology 83:548-551. doi:10.1094/Phyto-83-548

Peterson, C.J. 1992. Similarities among test sites based on cultivar performance in the hard red winter wheat region. Crop Sci. 32:907912. doi:10.2135/cropsci1992.0011183X003200040014x

Peterson, C.J., D.R. Shelton, P.S. Baenziger, D.D. Baltensperger, R.A. Graybosch, W.D. Worrall, et al. 2001. Registration of 'Wesley' wheat. Crop Sci. 41:260-261. doi:10.2135/cropsci2001.411260x

Rouse, M.N., R. Wanyera, P. Njau, and Y. Jin. 2011. Sources of resistance to stem rust race Ug99 in spring wheat germplasm. Plant Dis. 95:762-766. doi:10.1094/PDIS-12-10-0940

Schmidt, J.W., V.A. Johnson, A.F. Dreier, and P.J. Mattern. 1971. Registration of Scout 66 wheat. Crop Sci. 11:138.

Schmidt, J.W., V.A. Johnson, P.J. Mattern, A.F. Dreier, D.V. McVey, and J.H. Hatchett. 1989. Registration of 'Redland' wheat. Crop Sci. 29:491.

Sidiqi, J., S.N. Wegulo, P.E. Read, and P.S. Baenziger. 2009. Frequency of resistance to stem rust race TPMK in Afghan wheat cultivars. Can. J. Plant Pathol. 31:250-253. doi:10.1080/07060660909507598

Smith, E.L., O.G. Merkle, H.T. Nguyen, D.C. Abbott, and G.H. Morgan. 1985. Registration of Chisholm wheat. Crop Sci. 25:367-368. doi:10.2135/cropsci1985.0011183X002500020052x

Stroup, W.W., P.S. Baenziger, and D.K. Mulitze. 1994. A comparison of methods for removing spatial variation from wheat yield trials. Crop Sci. 34:62-66. doi:10.2135/cropsci1994.0011183X003400010011x

Watkins, J.E., J. Schimelfenig, P.S. Baenziger, and K.M. Eskrdige. 2001. Virulence of Puccinia triticina on wheat in Nebraska during 1997 and 1998. Plant Dis. 85:159-164. doi:10.1094/PDIS.2001.85.2.159

Wegulo, S.N., W.W. Backus, J.H. Nopsa, E.D. DeWolf, K.M. Eskridge, K.H.S. Peiris, and F.E. Dowell. 2011. Effects of integrating cultivar resistance and fungicide application on Fusarium head blight and deoxynivalenol in winter wheat. Plant Dis. 95:554-560. doi:10.1094/PDIS-07-10-0495

Welsh, J.R., G. Ellis, R. Normann, W.S. Ball, G. Hinze, and H. Mann. Registration of Vona wheat. 1978. Crop Sci. 18:695. doi:10.2135/ cropsci1978.0011183X0018000400 